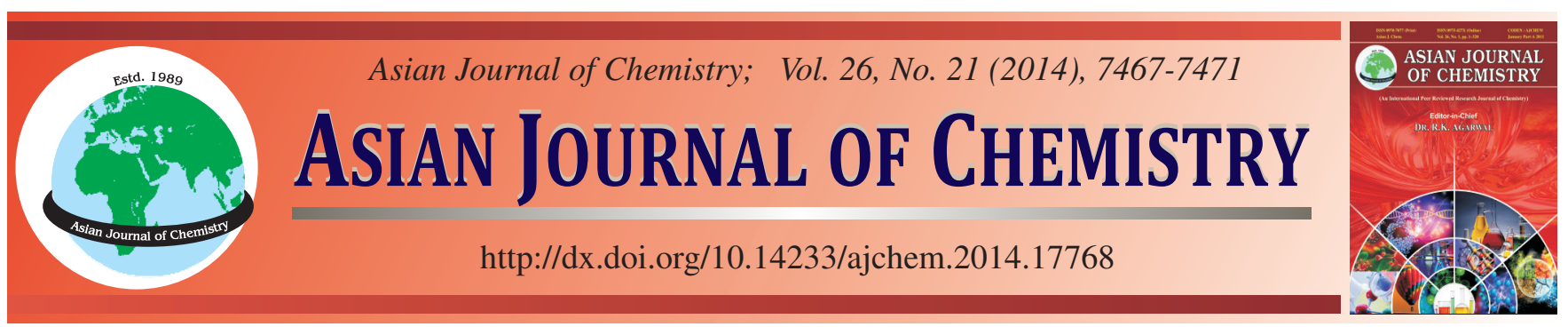

\title{
Synthesis of Thiosemicarbazones as Substrates for Xanthine Oxidase Enzyme Activity
}

\author{
S. BeYAZTAs ${ }^{1, *}$, E. FindiK ${ }^{2}$, M. CEYLAN ${ }^{2}$ and O. ArsLAn ${ }^{1}$
}

${ }^{1}$ Balikesir University, Science and Art Faculty, Department of Chemistry/Biochemistry Section, Balikesir, Turkey

${ }^{2}$ Gaziosmanpasa University, Science and Art Faculty, Department of Chemistry/Organic Chemistry Section, Tokat, Turkey

*Corresponding author: Fax: +90 266 6121215; Tel: +90 266 6121278; E-mail: beyaztas@ balikesir.edu.tr

Received: 5 April 2014;

Accepted: 1 July 2014;

Published online: 30 September 2014;

AJC-16164

\begin{abstract}
Thiosemicarbazones were synthesized from 7-arylbicyclo[3.2.0]hept-2-en-6-ones (1a-d) and thiosemicarbazide. The compounds were purified on a silica gel column chromatography. The thiosemicarbazone compounds were tested in vitro effect on xanthine oxidase (XO) purified from bovine milk. These compounds exhibited activator effects on xanthine oxidase enzyme activity at low concentration. We examined $K_{M}$ and $V_{\max }$ values for thiosemicarbazone derivatives at different $\mathrm{pH}$ values. The derivatives showed better values of $\mathrm{K}_{\mathrm{M}}, \mathrm{V}_{\max }$ and $\mathrm{V}_{\max } / \mathrm{K}_{\mathrm{M}}$ than xanthine. Particularly, (Z)-1-((1R,5S,E)-7-(4-methylbenzylidene)bicyclo[3.2.0]hept-2-en-6-ylidene) thiosemicarbazide (4Mtc) was the most suitable substrate, due to the lowest $\mathrm{K}_{\mathrm{M}}$ and the highest $\mathrm{V}_{\max } / \mathrm{K}_{\mathrm{M}}$ values. $\mathrm{K}_{\mathrm{M}}$ and $\mathrm{V}_{\max } / \mathrm{K}_{\mathrm{M}}$ values were $1 \times 10^{-4} \mathrm{M}$ and $1.11 \times 10^{6} \mathrm{~min}^{-1}$, respectively. We proposed here a novel substrate for xanthine oxidase which can be used to assess the activity of this enzyme.
\end{abstract}

Keywords: Xanthine oxidase, in vitro Effect, Kinetic parameters, Substrate, Thiosemicarbazone derivatives.

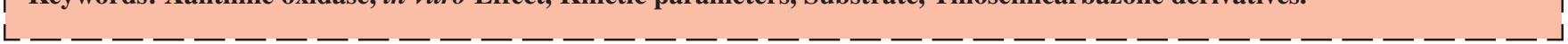

\section{INTRODUCTION}

Xanthine oxidoreductase (XOR) is a $290 \mathrm{kDa}$ molybdenum containing enzyme that has been studied extensively from a biochemical perspective for more than hundred years ${ }^{1,2}$. The enzyme is synthesized as xanthine dehydrogenase (XD; EC 1.1.3.204), but can be readily converted to xanthine oxidase (XO; EC 1.2.3.22) by oxidation of sulfhydryl residues or by proteolysis ${ }^{3-5}$. Xanthine dehydrogenase utilizes $\mathrm{NAD}^{+}$as an electron acceptor and xanthine oxidase utilizes $\mathrm{O}_{2}$ as an electron acceptor $^{6-8}$. Xanthine oxidase is situated at the end of catabolic reactions of the purine nucleotide metabolism in humans and a few other uricotelic species. Its major function is to catalyze the oxidation of hypoxanthine to xanthine and xanthine to uric $\mathrm{acid}^{4}$. Xanthine oxidase is widely distributed throughout various organs including the liver, gut, lung, kidney, heart and brain, as well as the plasma ${ }^{9-14}$. Xanthine oxidase is considered to be a main source of oxidative stress and destructive free radicals in ischemia-reperfusion injury associated with heart attacks and stroke and in spinal cord injury, as well as being a destructive force in myocardial or renal hypoxia and infarctions ${ }^{16-18}$.

Xanthine oxidase catalyzes the hydroxylation of carbon atoms of a wide variety of substrates, including hypoxanthine and xanthine, which are the physiological substrates in many organisms ${ }^{12,13}$. Purines such as hypoxanthine and xanthine are good substrates for xanthine oxidase ${ }^{2,15}$. Its mechanism of action, which was very complex, had been extensively studied, in many instances with the use of non-physiological substrates ${ }^{11}$.

In this study, we studied effect of new thiosemicarbazone derivatives on xanthine oxidase. These compounds and their metal complexes have a wide range of biological properties ${ }^{19}$. Because of this, a large number of organic and metal-organic compounds derived from thiosemicarbazone have been the subject of most structural and medicinal studies. Some of the detected biological activities of the thiosemicarbazones are antibacterial, antifungal, antiarthritic, antimalarial, antiamebic, antitumor, antiviral and anti-HIV ${ }^{20}$. Thiosemicarbazone derivatives usually react as ligands for metal cations by bonding through the sulphur and the azomethinic nitrogen atoms $\mathrm{s}^{21,22}$. Therefore, the search for clinically useful thiosemicarbazone is a growing field of interest. In this study, we describe a containing thione group and study their properties as a substrate of xanthine oxidase purified from bovine milk.

\section{EXPERIMENTAL}

Melting points of the compounds were measured using Electrothermal 9100 apparatus. IR spectrums (KBr or liquid) were taken by a Jasco FT/IR-430 Infrared spectrophotometer. ${ }^{1} \mathrm{H}$ and ${ }^{13} \mathrm{C}$ NMR spectra were recorded using a Brucker Avance III instrument using TMS $(\delta 0.00)$ for ${ }^{1} \mathrm{H}$ NMR and $\mathrm{CDCl}_{3}$ 
$(\delta 77.0)$ for ${ }^{13} \mathrm{C}$ NMR spectroscopy as internal reference standards $\mathrm{J}$ values were given in $\mathrm{Hz}$. The multiplicities of the signals in the ${ }^{1} \mathrm{H}$ NMR spectra are abbreviated by s (singlet), $\mathrm{d}$ (doublet), t (triplet), q (quarted), m (multiplet), br (broad) and combinations thereof. Elemental analyses were obtained from a LECO CHNS 932 Elemental Analyzer.

Sepharose 4B, L-tyrosine, benzamidine, protein assay reagents and chemicals for electrophoresis were obtained from Sigma Chem. Co. All other chemicals used were of analytical grade and obtained from either Sigma or Merck.

General procedure for synthesis of compounds: A solution of starting compounds 7-arylbicyclo[3.2.0]hept-2-en-6ones (1a-d) and thiosemicarbazide $(1: 1)$ in ethanol was refluxed for $3 \mathrm{~h}$. After the removal of the ethanol (Scheme-I), the crude product was purified on a silica gel column chromatography eluting with ethyl acetate-hexane.

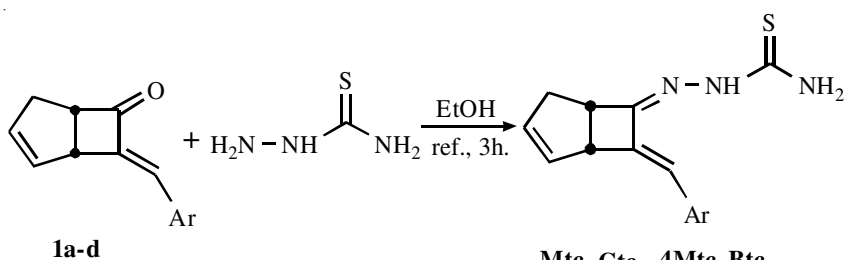

Scheme-I: Synthesis of thiosemicarbazone derivatives (Mtc, 4Mtc, Ctc and Btc)

(Z)-1-((1R,5S,E)-7-(4-Methoxybenzylidene)bicyclo[3.2.0]hept-2-en-6-ylidene) thiosemicarbazide (Mtc): Yield, $80 \%$; yellowish solid m.p. $167-169{ }^{\circ} \mathrm{C} .{ }^{1} \mathrm{H}$ NMR $(400 \mathrm{MHz}$, $\mathrm{CDCl}_{3}$ ): $\delta=10.82(\mathrm{~s}, 1 \mathrm{H},-\mathrm{NH}), 8.13\left(\mathrm{~s}, 1 \mathrm{H},-\mathrm{NH}_{2}\right), 7.65$ (s, $\left.1 \mathrm{H},-\mathrm{NH}_{2}\right), 7.43(\mathrm{~d}, J=8.8 \mathrm{~Hz}, 2 \mathrm{H}, \mathrm{A}$ part of AB system), 6.95 $(\mathrm{d}, J=8.8 \mathrm{~Hz}, 2 \mathrm{H}, \mathrm{B}$ part of AB system), $6.68(\mathrm{~s}, 1 \mathrm{H}), 5.95$ (m, 1H, A part of AB system), $5.80(\mathrm{~m}, 1 \mathrm{H}, \mathrm{B}$ part of $\mathrm{AB}$ system), 4.21 (m, 1H, A part of AB system), 3.96 (m, 1H, B part of $\mathrm{AB}$ system), 3.75 (s, 3H, $\left.-\mathrm{OCH}_{3}\right), 2.51(\mathrm{~m}, 2 \mathrm{H}) .{ }^{13} \mathrm{C}-$ NMR $\left(100 \mathrm{MHz}, \mathrm{CDCl}_{3}\right): \delta=178.37,159.65,154.92,141.70$, 132.96, 130.14 (2C), 129.04, 128.64, 119.48, 114.96 (2C), 55.63, 51.46, 46.87, 35.22. IR ( $\left.\mathrm{KBr}, \mathrm{v}_{\max }, \mathrm{cm}^{-1}\right)$ : 3459, 3340, 1600, 1587, 1506. Anal. Calcd. for $\mathrm{C}_{16} \mathrm{H}_{17} \mathrm{~N}_{3} \mathrm{OS}$ : C, 64.19; $\mathrm{H}$, 5.72; N, 14.04; S, 10.71. Found: C, 64.36; H, 5.58; N, 14.24; S, 10.93

(Z)-1-((1R,5S,E)-7-(4-Chlorobenzylidene)bicyclo[3.2.0]hept-2-en-6-ylidene) thiosemicarbazide (Ctc): Yield, $87 \%$; yellowish solid m.p. $183-185^{\circ} \mathrm{C} .{ }^{1} \mathrm{H}$ NMR $(400 \mathrm{MHz}$, $\left.\mathrm{CDCl}_{3}\right): \delta=10.95(\mathrm{~s}, 1 \mathrm{H},-\mathrm{NH}), 8.2\left(\mathrm{~s}, 1 \mathrm{H},-\mathrm{NH}_{2}\right), 7.71(\mathrm{~s}$, $\left.1 \mathrm{H},-\mathrm{NH}_{2}\right), 7.49$ (d, J=8.6 Hz, 2H, A part of AB system), 7.43 (d, $J=8.6 \mathrm{~Hz}, 2 \mathrm{H}$, B part of AB system), 6.72 (s, 1H, olefinic), 5.94 (m, 1H, A part of AB system), 5.82 (m, 1H, B part of AB system), 4.26 (m, 1H, A part of AB system), 3.98 (m, 1H, B part of $\mathrm{AB}$ system), $2.55(\mathrm{~m}, 2 \mathrm{H}) .{ }^{13} \mathrm{C} \mathrm{NMR}\left(100 \mathrm{MHz}, \mathrm{CDCl}_{3}\right)$ : $\delta=154.01,145.26,134.87,133.33,132.84,130.17$ (2C), 129.45 (2C), 128.61, 118.22, 51.66, 47.03, 35.01. IR (KBr, $\left.V_{\max }, \mathrm{cm}^{-1}\right): 3448,3255,1583,1508,1452$. Anal. Calcd. for $\mathrm{C}_{15} \mathrm{H}_{14} \mathrm{ClN}_{3} \mathrm{~S}$ : C, 59.30; H, 4.64; N, 13.83; S, 10.55. Found: C, 59.12; H, 4.56; N, 13.98; S, 10.78 .

(Z)-1-((1R,5S,E)-7-(4-Methylbenzylidene)bicyclo[3.2.0]hept-2-en-6-ylidene) thiosemicarbazide (4Mtc): Yield, $85 \%$, yellowish solid m.p. $174-176{ }^{\circ} \mathrm{C} .{ }^{1} \mathrm{H}$ NMR (400 $\left.\mathrm{MHz}, \mathrm{CDCl}_{3}\right): \delta=10.86(\mathrm{~s}, 1 \mathrm{H},-\mathrm{NH}), 8.16\left(\mathrm{~s}, 1 \mathrm{H},-\mathrm{NH}_{2}\right)$, $7.68\left(\mathrm{~s}, 1 \mathrm{H},-\mathrm{NH}_{2}\right), 7.37(\mathrm{~d}, J=7.2 \mathrm{~Hz}, 2 \mathrm{H}, \mathrm{A}$ part of $\mathrm{AB}$ system), 7.17 (d, $J=7.2 \mathrm{~Hz}, 2 \mathrm{H}, \mathrm{B}$ part of AB system), 6.70 (s, 1H, olefinic), $5.93(\mathrm{~m}, 1 \mathrm{H}, \mathrm{A}$ part of AB system), $5.75(\mathrm{~m}$, 1H, B part of AB system), 4.22 (m, 1H, A part of AB system), 3.97 (m, 1H, B part of AB system), 2.51 (m, 2H), 2.27 (s, 3H, $\left.-\mathrm{CH}_{3}\right) .{ }^{13} \mathrm{C} \mathrm{NMR}\left(100 \mathrm{MHz}, \mathrm{CDCl}_{3}\right): \delta=178.47,159.90,154.65$, 143.28, 138.10, 133.21, 133.03, 130.04 (2C), 128.59 (2C), 119.67, 151.66, 46.93, 35.28, 21.38. IR (KBr, $\left.v_{\max }, \mathrm{cm}^{-1}\right): 3502$, 3369, 1573, 1508, 1436. Anal. Calcd. for $\mathrm{C}_{16} \mathrm{H}_{17} \mathrm{~N}_{3} \mathrm{~S}$ : C, 67.81; H, 6.05; N, 14.83; S, 11.31. Found: C, 67.97; H, 6.23; N, 14.99; S, 11.54 .

(Z)-1-((1R,5S,E)-7-(4-Bromobenzylidene)bicyclo[3.2.0] hept-2-en-6-ylidene) thiosemicarbazide (Btc): Yield, $80 \%$, yellowish solid m.p. $169-171{ }^{\circ} \mathrm{C} .{ }^{1} \mathrm{H}$ NMR $(400 \mathrm{MHz}$, $\left.\mathrm{CDCl}_{3}\right): \delta=10.95(\mathrm{~s}, 1 \mathrm{H},-\mathrm{NH}), 8.23\left(\mathrm{~s}, 1 \mathrm{H},-\mathrm{NH}_{2}\right), 7.71(\mathrm{~s}$, $\left.1 \mathrm{H},-\mathrm{NH}_{2}\right), 7.56(\mathrm{~d}, J=8.4 \mathrm{~Hz}, 2 \mathrm{H}, \mathrm{A}$ part of AB system), 7.42 (d, $J=8.4 \mathrm{~Hz}, 2 \mathrm{H}, \mathrm{B}$ part of AB system), 6.70 (s, 1H, olefinic), $5.93(\mathrm{~m}, 1 \mathrm{H}, \mathrm{A}$ part of $\mathrm{AB}$ system), 5.81 (m, 1H, B part of AB system), 4.25 (m, 1H, A part of AB system), 3.98 (m, 1H, B part of AB system), 2.61-2.49 (m, 2H). ${ }^{13} \mathrm{C} \mathrm{NMR} \mathrm{(100} \mathrm{MHz,}$ $\left.\mathrm{CDCl}_{3}\right): \delta=178.64,154.01,145.38,135.19,133.34,132.36$ (2C), 130.44 (2C), 128.57, 121.52, 118.30, 51.96, 47.03, 35.36. IR $\left(\mathrm{KBr}, \mathrm{v}_{\max }, \mathrm{cm}^{-1}\right): 3438,3257,1583,1508,1452$. Anal. Calcd. for $\mathrm{C}_{15} \mathrm{H}_{14} \mathrm{BrN}_{3} \mathrm{~S}$ : C, 51.73; H, 4.05; N, 12.07; S, 9.21. Found: C, 51.62; H, 4.32; N, 12.27; S, 9.44.

Enzyme purification: Fresh bovine milk, without added preservative, was cooled down to $4{ }^{\circ} \mathrm{C}$, overnight. EDTA and toluene were added to give final concentrations of $2 \mathrm{mM}$ and $3 \%$ (v/v), respectively. The milk was churned with a blender at top speed for $0.5 \mathrm{~h}$ at room temperature. This sample was brought to $38 \%$ saturation by addition of solid ammonium sulphate $^{23}$. The suspension was centrifuged at $15000 \mathrm{rpm}$ for $0.5 \mathrm{~h}$ and the precipitate formed was discarded. The supernatant was brought to $50 \%$ saturation with solid ammonium sulphate. The precipitate formed was collected by centrifugation at $15000 \mathrm{rpm}$ for $1 \mathrm{~h}$ and dissolved $0.1 \mathrm{M}$ tris- $\mathrm{HCl}(\mathrm{pH}=7.6)$.

The pooled precipitate obtained from bovine milk by using ammonium sulphate precipitation was subjected to affinity chromatography. The sample prior to that was loaded onto the affinity column containing benzamidine.

Affinity column equilibrated in $0.1 \mathrm{M}$ glycine/ $0.1 \mathrm{M} \mathrm{NaCl}$ $(\mathrm{pH}=9)$. The sample was applied to the affinity gel. The affinity gel was washed with $0.1 \mathrm{M}$ glycine $(\mathrm{pH}=9)$. Xanthine oxidase, was eluted with $25 \mathrm{mM}$ benzamidine in $0.1 \mathrm{M}$ glycine/0.1 M $\mathrm{NaCl}(\mathrm{pH}=9)$. Fractions of $1.5 \mathrm{~mL}$ were collected and their absorbance measured at $280 \mathrm{~nm}$.

Activity measurements: Xanthine oxidase activity was determined at $37^{\circ} \mathrm{C}$ by the modified method of Massey et al..$^{24}$. The conversion of xanthine uric acid was followed by monitoring the change in absorbance at $295 \mathrm{~nm}$, using CARY $1 \mathrm{E}, \mathrm{UV}$-visible spectrophotometer $\left(\varepsilon_{292}=9.5 \mathrm{mM}^{-1} \mathrm{~cm}^{-1}\right)$. The reaction mixture contained $50 \mathrm{mM}$ tris $-\mathrm{HCl}(\mathrm{pH}=7.6)$ and $0.15 \mathrm{mM}$ xanthine, at $37^{\circ} \mathrm{C}$. The assay was initiated by the addition of the enzyme. One unit of enzyme activity was defined as the amount of enzyme that converts one $\mu$ mol of xanthine to uric acid per min under defined conditions ${ }^{23}$.

in vitro Activation kinetic studies: For the activation studies of some thiosemicarbazone derivatives, different 
concentration were added to the enzyme activity. Xanthine oxidase enzyme activity with thiosemicarbazone derivatives were assayed by following the oxidation of xanthine. Activity $\%$ values of xanthine oxidase for six different concentrations of thiosemicarbazone derivatives were determined by regression analysis using Microsoft Office 2000 Excel. Xanthine oxidase activity without thiosemicarbazone derivative was accepted as $100 \%$ active. The graphs exhibited the new thiosemicarbazone derivatives which were activator effect on the enzyme.

In addition, $\mathrm{K}_{\mathrm{M}}$ and $\mathrm{V}_{\max }$ values of the enzyme were determined on xanthine oxidase activity using different $\mathrm{pH}$ values. In order to achieve this, new thiosemicarbazone derivatives as a substrate were measured at different substrate concentrations at $37{ }^{\circ} \mathrm{C}$. $\mathrm{K}_{\mathrm{M}}$ and $\mathrm{V}_{\max }$ values were determined by means of Lineweaver-Burke graphs.

Determination of total protein: The absorbance at 280 $\mathrm{nm}$ was used to monitor the protein in the column effluents. Quantitative protein determination was achieved by absorbance measurements at $595 \mathrm{~nm}$ according to Bradford method ${ }^{25}$ with bovine serum albumin using as a standard.

Sodium dodecyl sulphate-polyacrylamide gel electrophoresis: Sodium dodecyl sulphate (SDS) polyacrylamide gel electrophoresis was performed after having a purified enzyme. It was carried out in 10 and $3 \%$ acrylamide-bisacrylamide concentration for the running and stacking gel, respectively, containing $0.1 \%$ SDS according to Laemmli method ${ }^{26}$. Sample was applied to the electrophoresis medium. Gel was stained overnight in $0.1 \%$ Coomassie Brilliant Blue R-250 in $50 \%$ methanol and $10 \%$ acetic acid, then destained by frequently changing the same solvent, without using dye. The electrophoretic pattern was photographed with the system of produce as an image of the gel (Fig. 1).
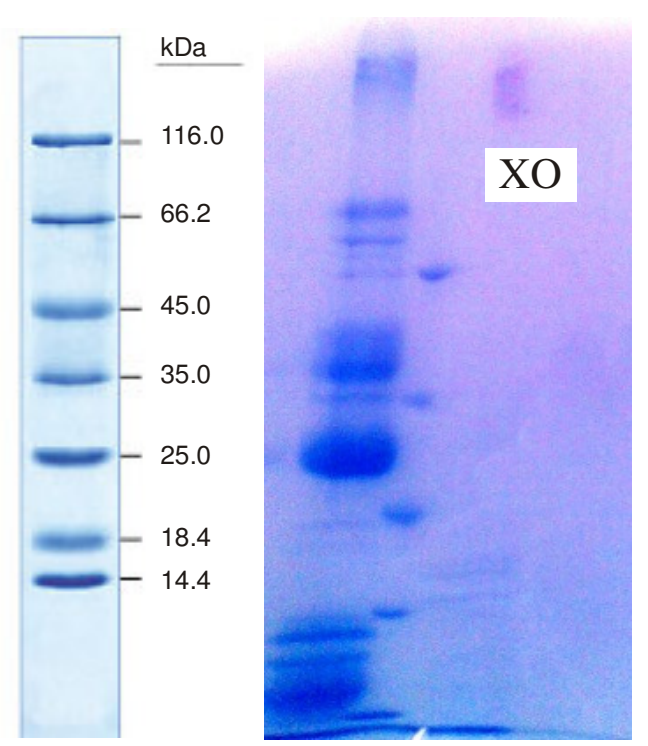

Fig. 1. SDS-PAGE pattern of xanthine oxidase. The poled fractions from affinity chromatography was analyzed by SDS-PAGE (12\% and 3 $\%)$ and revealed by Coomassie Blue staining. Experimental conditions were as described in the method. Lane 1 contained $5 \mu \mathrm{L}$ of various molecular mass standards: 3-galactosidase, (116.0), bovine serum albumin (66.2), ovalbumin (45), lactate dehydrogenase, (35.0), Restriction endonuclease (25), 3-lactoglobulin (18.4), lysozyme (14.4)

\section{RESULTS AND DISCUSSION}

Xanthine oxidase is also plentiful in milk, which has made it a popular enzyme for study since it is easy to isolate and purify ${ }^{13,27-30}$. Xanthine oxidase, a cellular redox enzyme, is highly expressed in mammary epithelial cells ${ }^{30}$ but xanthine oxidase was extracted from fresh bovine milk without added preservative using toluene and EDTA in this study. Toluene together with the gradual increase in temperature (from 4 to $45^{\circ} \mathrm{C}$ ) during churning caused an efficient extraction of the enzyme from lipid micelles. Filtration of the churned milk through filtration paper could be fractionated directly with ammonium sulphate. The entire enzyme was successfully collected in a narrow range of ammonium sulphate concentration. At this step, a 35-fold purification was achieved ${ }^{30-32}$. The precipitate form was collected and dissolved. The affinity gel was equilibrated and the dissolved sample prior to that was loaded onto an affinity column containing benzamidine. Gel was washed and xanthine oxidase was eluted. Fractions were collected and their absorbance measured at $280 \mathrm{~nm}$.

Firstly, we examined the in vitro effects of original thiosemicarbazone derivatives (Fig. 2). The starting thiosemicarbazone derivatives 1a-d (Scheme-I.) were first of all synthesized by the condensation of cis-bicyclo[3.2.0]hept-2-en-6one with corresponding aldehydes according to the recently published procedure ${ }^{33}$. Then thiosemicarbazide was added to compounds 1a-d in ethanol under the reflux conditions which gave the thiosemicarbazone derivatives (Mtc, 4Mtc, Ctc and Btc) in good yields (Scheme-I).

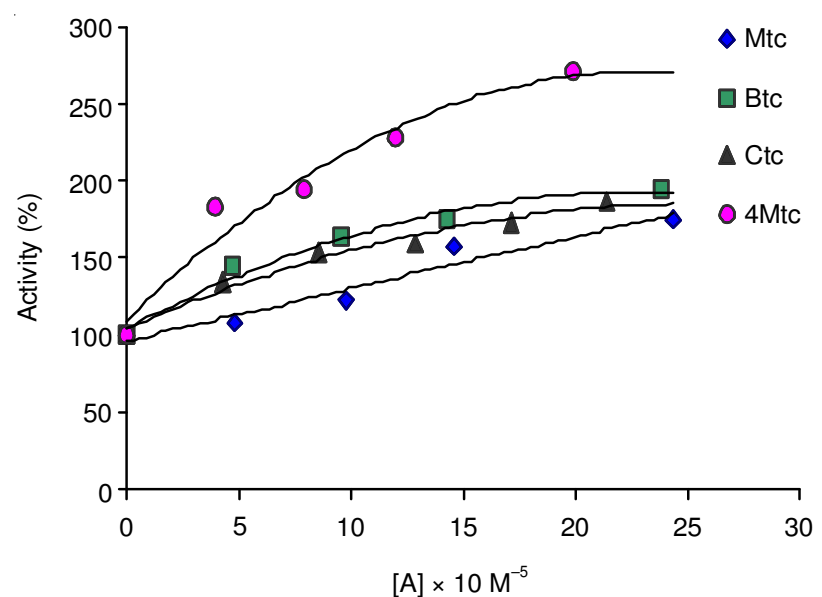

Fig. 2. Effect of Mtc, $4 \mathrm{Mtc}, \mathrm{Ctc}$ and Btc on xanthine oxidase enzyme activity. Effect of Mtc, 4Mtc, Ctc and Btc on the enzyme activity of a purified xanthine oxidase from milk was assayed for enzyme activity in the presence of various concentrations of above thiosemicarbazone derivatives. The experimental conditions were $50 \mathrm{mM}$ tris- $\mathrm{HCl}(\mathrm{pH}=7.6), 0.15 \mathrm{mM}$ xanthine and $37{ }^{\circ} \mathrm{C}$, constant concentration of enzyme. The five spectrophotometric measurement were made every 30 second by CARY $1 \mathrm{E}$, UV-visible spectrophotometer $\left(\lambda_{292}=9.5 \mathrm{mM}^{-1} \mathrm{~cm}^{-1}\right)$ at a wavelength of $295 \mathrm{~nm}$

Xanthine and hypoxanthine ${ }^{34}$ as substrate are commonly used to measure activity in xanthine oxidase ${ }^{11}$. Fig. 2 showed the original thiosemicarbazone derivatives behaviour which raised the xanthine oxidase enzyme activity. Because of this ability of the compounds, we studied these compounds to discover whether the original compounds were used as a 
substrate or not. $\mathrm{K}_{\mathrm{M}}$ and $\mathrm{V}_{\max }$ values of the enzyme were determined on xanthine oxidase activity using different $\mathrm{pH}$ values. In order to obtain these results, the thiosemicarbazone derivatives as a substrate were measured at different substrate concentrations at $37{ }^{\circ} \mathrm{C} . \mathrm{K}_{\mathrm{M}}$ and $\mathrm{V}_{\max }$ values were determined by means of Lineweaver-Burk graphs (Fig. 3, Table-3). $\mathrm{K}_{\mathrm{M}}$ and $\mathrm{V}_{\max }$ values for these compounds weren't determinated using tris- $\mathrm{HCl}(\mathrm{pH}=5)$ and tris-base $(\mathrm{pH}=9)$ buffers. Because, this value is not meaningful with each other. $K_{M}$ and $V_{\max }$ values of the enzyme were determined xanthine oxidase activity using tris- $\mathrm{HCl}(\mathrm{pH}=7.6)$ and different xanthine concentrations at $37{ }^{\circ} \mathrm{C}$.

The $\mathrm{K}_{\mathrm{M}}$ and $\mathrm{V}_{\max }$ were determined using xanthine by Lineweaver-Burke graphs, $1.7 \times 10^{-4} \mathrm{M}$ and $0.58 \mathrm{EU} / \mathrm{mL} / \mathrm{min}$, respectively (Table-1). $\mathrm{V}_{\max }$ was determined for Mtc, 4Mtc and Ctc $1 \times 10^{-3} \mathrm{U} / \mathrm{mL} / \mathrm{min}, 5.95 \times 10^{-3} \mathrm{EU} / \mathrm{mL} / \mathrm{min}, 0.32 \times 10^{-3}$ $\mathrm{EU} / \mathrm{mL} / \mathrm{min}$ using tris- $\mathrm{HCl}(\mathrm{pH}=6) . \mathrm{K}_{\mathrm{M}}$ values were found $2.01 \times 10^{-4} \mathrm{M}$., $2 \times 10^{-3}$ and $9.03 \times 10^{-5} \mathrm{M}$ with the same buffer, respectively. According to the results, $\mathrm{K}_{\mathrm{M}}$ and $\mathrm{V}_{\max }$ values didn't give a meaningful value using tris- $\mathrm{HCl}(\mathrm{pH}=6)$ buffer for Btc (Table-1). $\mathrm{K}_{\mathrm{M}}$ and $\mathrm{V}_{\max }$ values were also seen in Table-1 for Mtc, 4Mtc, Btc and Ctc using tris- $\mathrm{HCl}(\mathrm{pH}=7)$ and trisBase $(\mathrm{pH}=8)$ buffers. tris- $\mathrm{HCl}(\mathrm{pH}=8)$ is the best buffer for having a highest enzyme activity due to the lowest $\mathrm{K}_{\mathrm{M}}$ and the biggest $\mathrm{V}_{\max }$ values for all the thiosemicarbazones (Table-1).

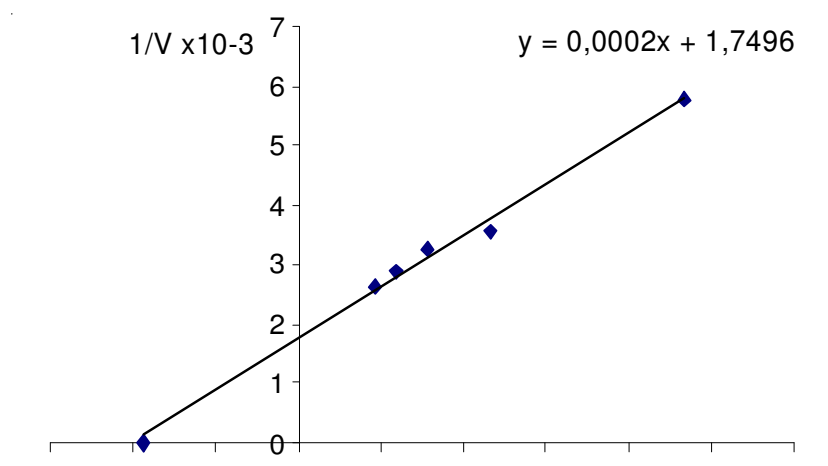

$-15000-10000-5000 \quad 0 \quad 50001000015000200002500030000$

(a)

$1 /[S]$

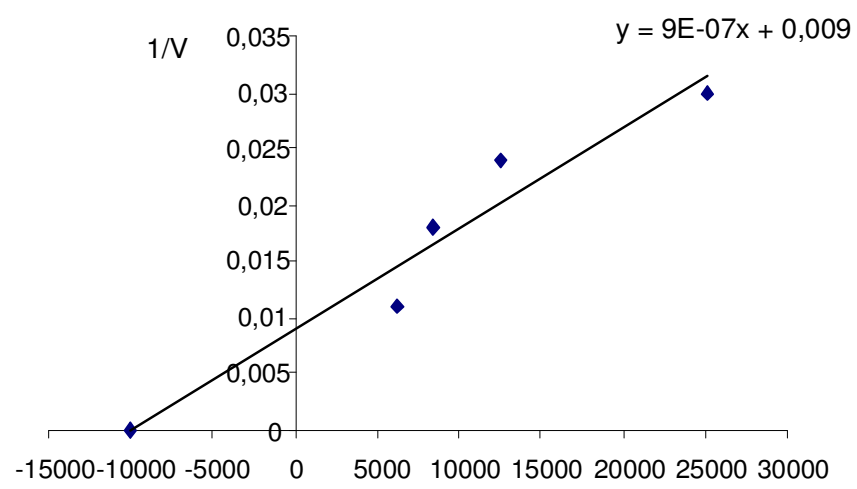

(c)

$1 /[\mathrm{S}]$
For xanthine oxidase, all reactions were conducted at the optimal $\mathrm{pH} 8$, too. In another study, the relative $\mathrm{V}_{\max }$ values for hypoxanthine, xanthine and 6-thioxanthine were similar, as were their $K_{M}$ values ${ }^{11}$.
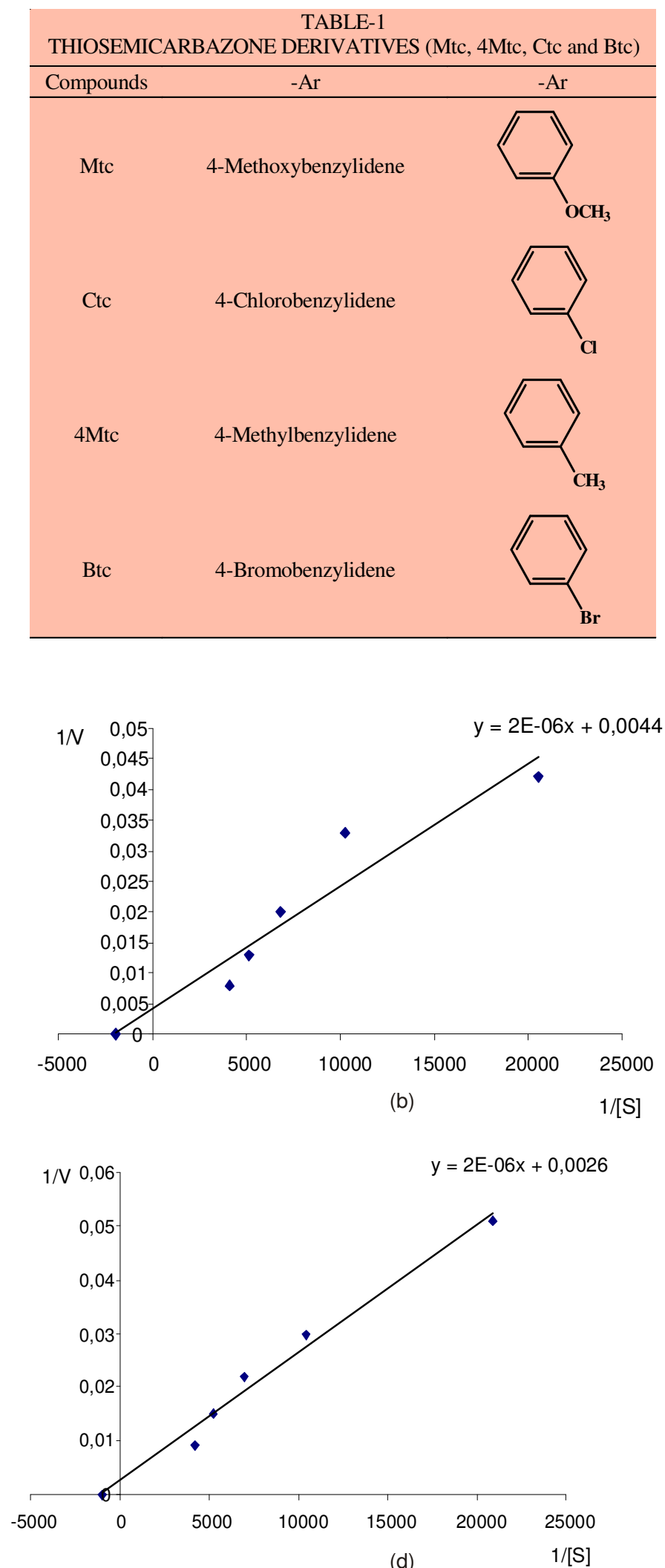

Fig. 3. $\mathrm{K}_{\mathrm{M}}$ and $\mathrm{V}_{\max }$ values of original thiosemicarbazone derivatives for xanthine oxidase. (a) Ctc. The experimental conditions were $50 \mathrm{mM}$ tris- $\mathrm{HCl}$ ( $\mathrm{pH}$

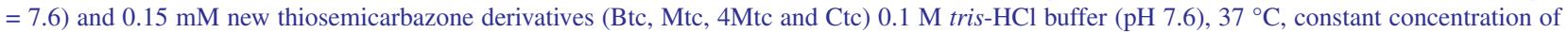

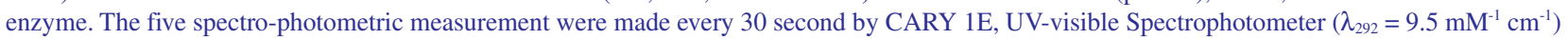
at a wavelength of $295 \mathrm{~nm}$. $\mathrm{K}_{\mathrm{M}}$ and $\mathrm{V}_{\max }$ graphics using new thiosemicarbazone derivatives were (a) Ctc, (b) Mtc, (c) 4Mtc and (d) Btc 


\begin{tabular}{|c|c|c|c|c|}
\hline \multicolumn{5}{|c|}{ 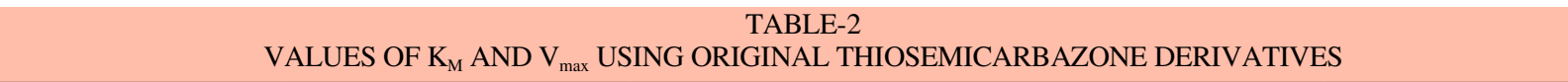 } \\
\hline $\mathrm{V}_{\max }(\mathrm{EU} / \mathrm{mL} / \min )$ & Mtc & $4 \mathrm{Mtc}$ & Btc & Ctc \\
\hline $\mathrm{pH}=6$ tris $-\mathrm{HCl}$ & $1 \times 10^{-3}$ & $5.95 \times 10^{-3}$ & Not found meaningful value & $0.32 \times 10^{-3}$ \\
\hline $\mathrm{pH}=7$ tris $-\mathrm{HCl}$ & 0.819 & $5.32 \times 10^{-3}$ & $2 \times 10^{-3}$ & $1.28 \times 10^{-3}$ \\
\hline $\mathrm{pH}=8$ tris - Base & 277.78 & 111.11 & 384.61 & 0.57 \\
\hline \multicolumn{5}{|c|}{$\mathrm{K}_{\mathrm{M}}(\mathrm{M})$} \\
\hline $\mathrm{pH}=6$ tris $-\mathrm{HCl}$ & $2.01 \times 10^{-4}$ & $2 \times 10^{-3}$ & Not found meaningful value & $9.03 \times 10^{-5}$ \\
\hline $\mathrm{pH}=7$ tris $-\mathrm{HCl}$ & $2.32 \times 10^{-4}$ & $3.22 \times 10^{-3}$ & $3.95 \times 10^{-4}$ & $1.79 \times 10^{-3}$ \\
\hline $\mathrm{pH}=8$ tris-Base & $5 \times 10^{-4}$ & $1 \times 10^{-4}$ & $1 \times 10^{-3}$ & $1.063 \times 10^{-4}$ \\
\hline
\end{tabular}

\begin{tabular}{ccccc}
\multicolumn{5}{c}{ TABLE-3 } \\
& \multicolumn{5}{c}{ VALUES OF $\mathrm{V}_{\text {max }} / \mathrm{K}_{\mathrm{M}}$ USING ORIGINAL THIOSEMICARBAZONE DERIVATIVES } \\
\hline $\mathrm{V}_{\max } / \mathrm{KM}(\mathrm{EU} / \mathrm{mL} \mathrm{M})$ & $\mathrm{Mtc}$ & $4 \mathrm{Mtc}$ & $\mathrm{Btc}$ & $\mathrm{Ctc}$ \\
\hline $\mathrm{pH}=6$ tris $-\mathrm{HCl}$ & 4.97 & 2.97 & - & 33.54 \\
$\mathrm{pH}=7$ tris $-\mathrm{HCl}$ & 353.02 & 1.65 & 5.06 & 0.71 \\
$\mathrm{pH}=8$ tris $-\mathrm{B}$ - & $55.56 \times 10^{4}$ & $11.11 \times 10^{5}$ & $38.46 \times 10^{4}$ & 5362.18 \\
\hline
\end{tabular}

Especially, the compounds were more suitable substrate according to using xanthine as a substrate with using tris-base $(\mathrm{pH}=8)$ buffer (Tables 1 and 2) But mostly in some studies xanthine is commonly used as a substrate to measure activity in xanthine oxidase ${ }^{30}$. Particularly, $4 \mathrm{Mtc}$ was the most suitable substrate, due to the lowest $\mathrm{K}_{\mathrm{M}}$ and the biggest $\mathrm{V}_{\max } / \mathrm{K}_{\mathrm{M}}$ values, followed by xanthine, Mtc, Ctc and Btc (Tables 1 and 2).

The thiosemicarbazones using as a substrate had better values of $\mathrm{K}_{\mathrm{M}}, \mathrm{V}_{\max }$ and $\mathrm{V}_{\max } / \mathrm{K}_{\mathrm{M}}$ comparing with xanthine. So here in this study the results were given the new thiosemicarbazones could be candidates as substrates in order to measure xanthine oxidase activity. tris-Base $(\mathrm{pH}=8)$ was the best buffer for measurement of xanthine oxidase enzyme activity for the new derivatives which the data's were also seen in Tables 1 and 2. Among the compounds, $4 \mathrm{Mtc}$ was the most suitable substrate. Also xanthine was given better results using $\mathrm{pH} 8$ buffers (Tables 1 and 2).

\section{Conclusion}

In humans, xanthine oxidase is normally found in the liver and not free in the blood. During severe liver damage, xanthine oxidase is released into the blood, so a blood assay for xanthine oxidase is a way to determine if liver damage has happened. So its regulation is also so important such as the lack of xanthine oxidase leads to high concentration of xanthine in blood and can cause health problems, for this purpose in this study we proposed novel substrates for xanthine oxidase which could be used to assess the activity of this enzyme regulation.

\section{ACKNOWLEDGEMENTS}

This work has been supported by Balikesir University Research Project (2009/17) and carried out at the Balikesir University Research Center of Applied Sciences (BURCAS).

\section{REFERENCES}

1. J.L. McManaman, M.C. Neville and R.M. Wright, Arch. Biochem. Biophys., 371, 308 (1999).

2. V. Massey, H. Komai, G. Palmer and G.B. Elion, J. Biol. Chem., 245, 2837 (1970)

3. R. Harrison, Free Radic. Biol. Med., 33, 774 (2002).

4. R. Harrison, Int. Dairy J., 16, 546 (2006).
5. N. Silanikove, F. Shapiro and G. Leitner, Biochem. Biophys. Res. Commun., 363, 561 (2007).

6. C. Galbusera, P. Orth, D. Fedida and T. Spector, Biochem. Pharmacol., 71, 1747 (2006).

7. J.M. Pauff and R. Hille, J. Nat. Prod., 72, 725 (2009).

8. R. Hille, Eur. J. Inorg. Chem., 2006, 1913 (2006).

9. K.R. Sathisha, S.A. Khanum, J.N.N.S. Chandra, F. Ayisha, S. Balaji, G.K. Marathe, S. Gopal and K.S. Rangappa, Bioorg. Med. Chem., 19, 211 (2011)

10. M.G. Bonini, S. Miyamoto, P.D. Mascio and O. Augusto, J. Chem. Biol., 279, 51836 (2004).

11. E. Kulikowska, B. Kierdaszuk and D. Shugar, Acta Biochim. Pol., 51, 493 (2004).

12. K. Okamoto, Y. Kawaguchi, B.T. Eger, E.F. Pai and T. Nishino, J. Am. Chem. Soc., 132, 17080 (2010).

13. T. Nishino, K. Okamoto, B.T. Eger, E.F. Pai and T. Nishino, FEBS J., 275, 3278 (2008).

14. Z.L. You, D.H. Shi, C. Xu, Q. Zhang and H.L. Zhu, Eur. J. Med. Chem., 43, 862 (2008)

15. J.H. Kim, J.A. Odutola, J. Popham, L. Jones and S. von Laven, J. Inorg. Biochem., 84, 145 (2001).

16. J. George and A. Struthers, J. Therap. Clinic Risk Manage., 5, 799 (2009).

17. D.M. Yellon and D. Hausenloy, J. N. Engl. J. Med., 357, 1121 (2007).

18. C. Li and R.M. Jackson, Am. J. Physiol. Cell Physiol., 282, 227 (2002).

19. Pal, F. Basuli and S. Bhattacharya, J. Chem. Sci., 114, 255 (2002).

20. I. Kizilcikli, Y.D. Kurt, B. Akkurt, A.Y. Genel, S. Birteksöz, G. Ötük and B. Ülküseven, Folia Microbiol. (Praha), 52, 15 (2007).

21. M.C. Rodriguez-Arguelles, M.B. Ferrari, G.G. Fava, C. Pelizzi, G. Pelosi, R. Albertini, A. Bonati, P.P. Dall'Aglio, P. Lunghi and S. Pinelli, J. Inorg. Biochem., 66, 7 (1997).

22. J. Perez, A. Matesanz, A. Martinambite, P. Navarro, C. Alonso and P. Souza, J. Inorg. Biochem., 75, 255 (1999).

23. N. Özer, M. Müftüoglu, D. Ataman, A. Ercan and I.H. Ögüs, J. Biochem. Biophys., 39, 153 (1999).

24. V. Massey, P.E. Brumby and H. Komai, J. Biol. Chem., 244, 1682 (1969).

25. M.M. Bradford, Anal. Biochem., 72, 248 (1976).

26. U.K. Laemmli, Nature, 227, 680 (1970).

27. R. Harrison, Drug Metab. Rev., 36, 363 (2004).

28. M.A. Hediger, R.J. Johnson, H. Miyazaki and H. Endou, Physiology (Bethesda), 20, 125 (2005).

29. R. Hille, Arch. Biochem. Biophys., 433, 107 (2005).

30. C.R. Stevens, T.M. Millar, J.G. Clinch, J.M. Kanczler, T. Bodamyali and D.R. Blake, Lancet, 356, 829 (2000).

31. A. Bytyqi-Damoni, H. Genç, M. Zengin, S. Beyaztas, N. Gençer and O. Arslan, Art. Cells Blood Subst. Biotech., 40, 369 (2012).

32. S. Beyaztas and O. Arslan, J. Biol. Chem., 39, 195 (2011).

33. M. Ceylan and E. Findik, Synth. Commun., 39, 1046 (2009).

34. R. Hile and T. Nishino, FASEB J., 9, 995 (1995). 